\title{
A Systematic Review on The Outcomes of Fibular Strut Graft for Femoral Neck Fractures In Adults
}

\author{
Bintang Soetjahjo ${ }^{1,2 *(1)}$, Udi Heru Nefihancoro ${ }^{1,2}$, Rieva Ermawan ${ }^{1,2}$, Rhyan Darma \\ Saputra ${ }^{1,2}$, Gilang Teguh Pratama ${ }^{2}$
}

\author{
${ }^{1}$ Departement of Orthopaedic and Traumatology, Dr. Moewardi General Hospital, Surakarta, Indonesia \\ ${ }^{2}$ Program Study of Orthopaedic and Traumatology, Dr. Moewardi General Hospital, Faculty of Medicine, Sebelas Maret \\ University, Surakarta, Indonesia
}

\section{A R T I C LE I N F O}

\section{Article history:}

Received 19 May 2021

Received in revised form 04 June 2021

Accepted 17 June 2021

Available online 30 June 2021

\section{Keywords:}

Femoral neck fractures,

Bone graft,

Fibural strut graft,

Systematic review

\section{*) Corresponding author:}

bjortho@yahoo.com

\begin{abstract}
A B S T R A C T
Introduction: Femoral neck fractures are a type of intracapsular hip fracture which also be found in younger patients who suffered from high-energy trauma such as vehicle accidents. Non-union and avascular necrosis are the most frequent complications following femoral neck fractures. In this study, we reviewed the outcomes of fibular grafting techniques for femoral neck fractures in adults. Methods: Online libraries PubMed, Cochrane Library and Scopus were searched for relevant papers. We searched for scientific publications published between 2009 and 2020. Inclusion and exclusion criteria were used, and prespecified characteristic were extracted from each study.

Results: We found 172 papers relevant to the topic. At last, we included 6 papers in this systematic review with a total of 198 patients. Fibular strut graft for femoral neck fractures have shown excellent outcomes, uniting 177 (89,39\%) of 198 fractures reviewed. Overall, 15 patients $(7,57 \%)$ experiencing non-union and 12 patients $(6,06 \%)$ having avascular necrosis.

Discussion: This interventions performed at a relatively low rate of complications. The techniques included in the studies were various, using vascularized or non-vascularized, using single or multiple cannulated cancellous screws or even dynamic hip screw. The decision on which method to use should be made by surgeons adjusting to the patients' conditions and needs.

Conclusion: The outcomes of the intervention turned out to be excellent, assessed by both functional outcome criteria and radiographic bony union. It is important to established a consensus on surgical intervention for femoral neck fractures, specifically including fibular strut grafting.
\end{abstract}

\section{Introduction}

Femoral neck fractures are a type of intracapsular hip fracture which is commonly found in elderly patients resulted from low-energy falls. However, these fractures may also be found in younger patients who suffered from high-energy trauma such as vehicle accidents. ${ }^{1,2}$ The medial femoral circumflex artery, which runs under the quadratus femoris is the main source of blood supply to the femoral head. Displaced fractures of the femoral neck can cause a decrease in the vascularization due to the tearing of the ascending cervical branches that stem off the arterial ring supply formed by the circumflex arteries. This may detain the fracture healing, inevitably causing non-union or osteonecrosis. ${ }^{3-5}$

Although surgical treatments for these fractures are refined, poor outcomes are not uncommon. Nonunion and avascular necrosis are the most frequent complications following femoral neck fractures. Until now, the optimal treatment (osteosynthesis versus replacement therapy) for femoral neck fractures remains controversial. ${ }^{6}$ Available osteosynthetic treatments are muscle pedicle bone graft, open/closed reduction with fibular grafting, and osteotomies with various implants. ${ }^{4,6}$

Recent studies have stated that fixation with fibular strut grafts prevents the subchondral collapse, acts as a biological implant and a channel for revascularization, and stimulates union effectively. Once this graft is revascularized, the osteoblasts stimulated by bone morphogenic protein can the resorbed bone. If this bone is appropriately stressed, the graft acquires sufficient strength to handle the load. ${ }^{3,4,6}$ Thus, in this study, we specifically reviewed the fibular grafting techniques for femoral neck fractures in adults, including the

Biomolecular and Health Science Journal

Available at https://e-journal.unair.ac.id/BHSJ ; DOI: 10.20473/bhsj.v4i1.26912 
vascularized and non-vascularized grafting, with or without cancellous screws. We assessed the outcomes of the techniques for both in fresh and neglected femoral neck fractures.

\section{Methods}

In this review, we used online database libraries namely PubMed, Cochrane, and Scopus to search for relevant papers. We searched for the articles using the Boolean logic with keywords "Fibular Graft AND Femoral Neck Fractures OR Neck of Femur Fractures". We also filtered the search for papers published between 2009 and 2020. The search process was performed again before this article submission for accommodating new articles.

The inclusion criteria of this review were randomized control trials, case controls, case series, and prospective or retrospective control study. The population of this study should in adults range of ages, both male or female. The intervention were fibular strut graft for femoral neck fractures, compared with control or placebo. We limited the study only written in English and with status published. The exclusion criteria were animal studies, descriptive studies, systematic review, meta-analysis and studies done in children. For two studies or more that using the same population, we choosed the most recent follow-up studies and the previous one was excluded.

All author information and affiliation of the studies were concealed to minimalize the reviewer selection bias. Two reviewers then screened the papers based on inclusion and exclusion criteria. Studies that did not meet the criteria were eliminated, as well as duplicated studies. We presented the selected papers using PRISMA method. ${ }^{7}$ The selected studies were then extracted based on pre-selected characteristic: author, year of publication, study design, gender, mean age, fracture grades, and type of interventions. The study later was group by outcomes evaluations, follow-ups, and complications.

\section{Results}

\section{Literature and Data Source}

We obtained 172 papers related to fibular strut graft for femoral neck fractures. Then, we analysed the papers with PRISMA Method and eliminated 16 duplicated papers. One hundred and two papers were excluded for not meeting the criteria for this study. Then, 48 papers that were out of topic were also excluded. At last, we had 6 papers to analyze in this systematic review. ${ }^{8-13}$
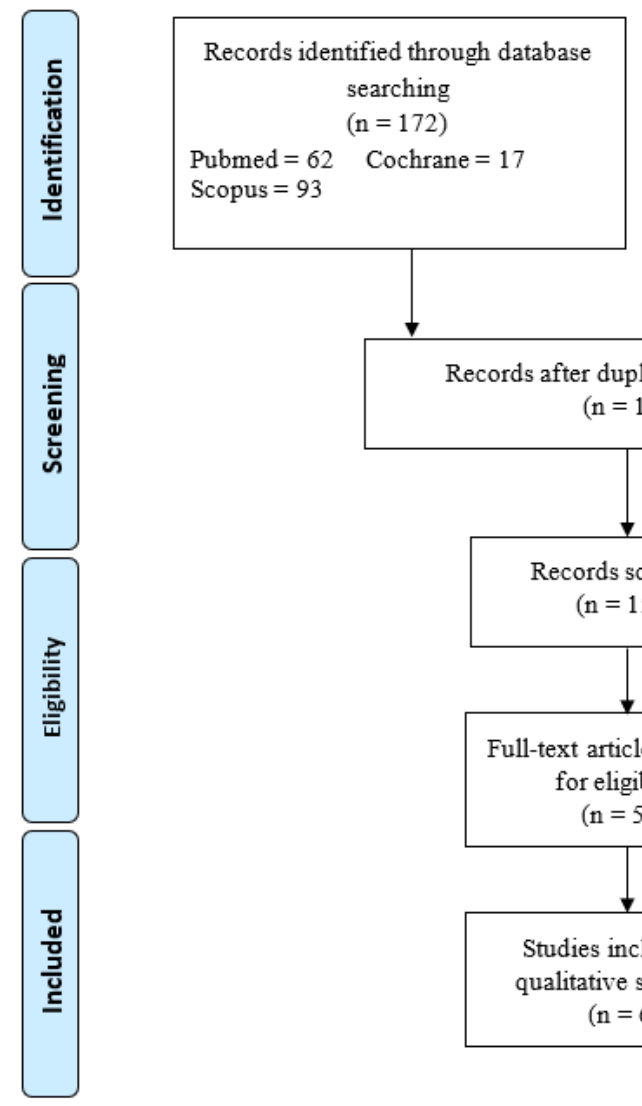

Records after duplicates removed $(\mathrm{n}=16)$

Additional records identified

through other sources $(\mathrm{n}=0)$
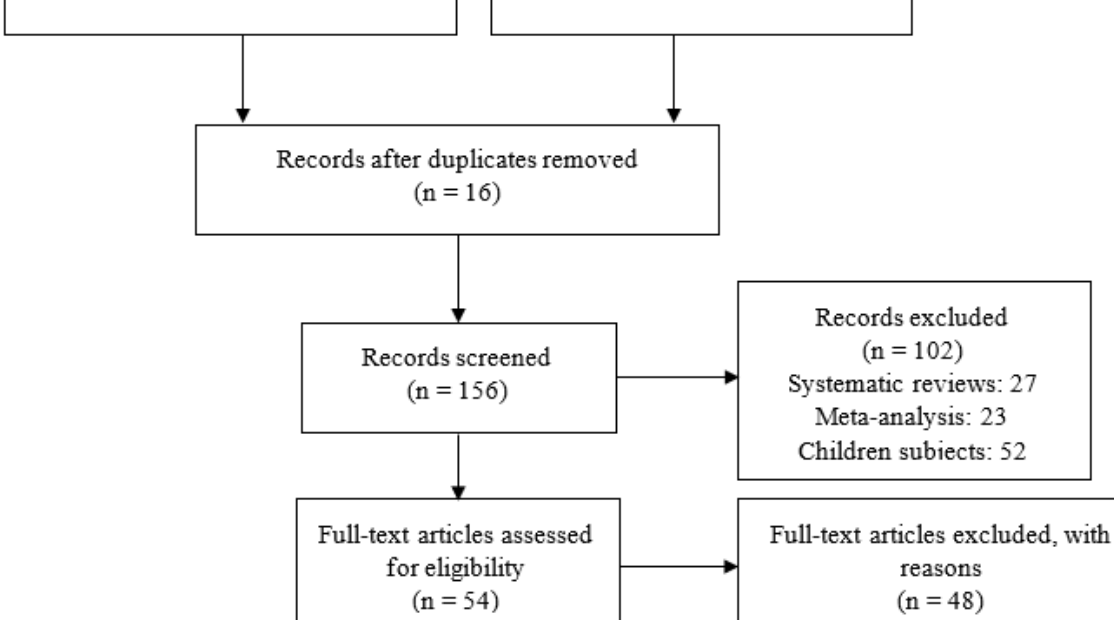

Not fibular strut: 12

Not femoral neck fractures: 36

Figure 1. Flow diagram of the selection process

\section{Details of Literatures on Fibular Strut Graft for Femoral Neck Fractures}

The details of literatures on fibular strut graft for femoral neck fractures were presented in Table 1. Five of the reviewed papers were retrospective studies, while one study was a case series. From the literature search, there were 198 patients with femoral neck fractures, both fresh and neglected fractures. The age of the patients was between 17 to 60 years old. There were 130 male patients and 68 female patients.

\section{Clinical Outcomes}

The clinical outcomes of the patients are summarized in Table 2. The fractures were classified with Garden grades 
II-IV (9,12-14) and Pauwels classification I-III. ${ }^{12}$ Most of the fibular strut graft interventions were also complemented with hip screws. The mean delay of interventions, mean time of follow up, and mean time of union are also presented in the table. The bony union was achieved in 177 cases $(89,39 \%)$ out of the 198 patients reviewed. The clinical outcomes were mostly evaluated using Harris Hip Score (9-13), while only one study used the Anglen criteria. ${ }^{8}$

\section{Complications}

The complications that occurred post-operatively are presented in Table 3. The most common major postoperative complications in femoral neck fractures are nonunion and avascular necrosis of the femoral head (15). In this study, out of the 198 patients reviewed, 15 patients $(7,57 \%)$ had non-union. Non-union itself is defines as gaps at the fracture site even after 6 months post-intervention (9). Avascular necrosis occurred in 12 patients $(6,06 \%)$ in total.

Table 1. Details of literatures on Fibular Strut Grafts for Femoral Neck Fractures

\begin{tabular}{|c|c|c|c|c|c|}
\hline Author & Study Design & Cases & Age & $\operatorname{Sex}(M / F)$ & Subject Criteria \\
\hline Azam et al, $2009^{8}$ & $\begin{array}{l}\text { Retrospective } \\
\text { Study }\end{array}$ & 32 & $37.8(22$ to 45$)$ & $22 / 10$ & $\begin{array}{l}\text { Patients with neglected femoral neck frac- } \\
\text { tures having a minimum follow-up of less } \\
\text { than three years. }\end{array}$ \\
\hline Zahid et al, $2012^{9}$ & $\begin{array}{l}\text { Retrospective } \\
\text { Study }\end{array}$ & 33 & $52(40$ to 60$)$ & $15 / 18$ & $\begin{array}{l}\text { Patients without posterior comminution or } \\
\text { those with fractures older than } 3 \text { weeks, }\end{array}$ \\
\hline $\begin{array}{l}\text { Chhetri et al, } \\
2019^{10}\end{array}$ & $\begin{array}{l}\text { Retrospective } \\
\text { Study }\end{array}$ & 20 & $38.6(18$ to 60$)$ & $14 / 6$ & $\begin{array}{l}\text { Patients with fracture neck of femur at least } \\
\text { three weeks from time of injury and under- } \\
\text { went surgery with fibular strut graft and two } \\
\text { cannulated hip screws during August } 2008 \text { to } \\
\text { December } 2017 \text {. }\end{array}$ \\
\hline $\begin{array}{l}\text { Elgeidi et al, } \\
2017^{11}\end{array}$ & $\begin{array}{l}\text { Retrospective } \\
\text { Study }\end{array}$ & 35 & $37(20$ to 50$)$ & $30 / 5$ & $\begin{array}{l}\text { Patients who had isolated fresh fracture neck } \\
\text { of femur less than } 3 \text { weeks at time of oper- } \\
\text { ation with Garden grades III and IV with } \\
\text { posterior comminution and with Pauwel's } \\
\text { grading were included. }\end{array}$ \\
\hline Pal et al, $2014^{12}$ & $\begin{array}{l}\text { Retrospective } \\
\text { Study }\end{array}$ & 72 & 17 to 50 & $44 / 28$ & $\begin{array}{l}\text { Neglected femoral neck fractures who under- } \\
\text { went fixation with double cancellous screws } \\
\text { with a single fibular strut graft or fixation with } \\
\text { a single cancellous screw with double fibular } \\
\text { strut grafts between July } 2004 \text { and June } 2007 \text {. }\end{array}$ \\
\hline $\begin{array}{l}\text { Wisesa et al, } \\
2020^{13}\end{array}$ & Case Series & 6 & 20 to 45 & $5 / 1$ & $\begin{array}{l}\text { Femoral neck fracture treated with multiple } \\
\text { cancellous screws either with or without } \\
\text { fibular graft between the period of January } \\
2016 \text { to January } 2018 \text { were included. }\end{array}$ \\
\hline
\end{tabular}

\section{Discussion}

This review aimed to assess the outcomes of fibular strut graft as a therapy for femoral neck fractures in adults, as well as the complications found within the follow-up period such as non-union and avascular necrosis. The interventions reviewed in this study were various, either using a single screw or multiple screws, both for fresh and neglected femoral neck fractures. This study also happened to review these different methods. In addition, this review also included one study which compared the outcome of intervention using cancellous screws with and without fibular graft.

In fibular strut grafting, the reduction and fixation are done after freshening the fracture surfaces. The reduction can be either closed or open. Some clinicians used open reduction and placed cancellous autograft along with fibula. Fibula, as a cortical bone can provide mechanical strength while also stimulating union as a biological graft ${ }^{4}$

Half of the studies summarized in this review are treating neglected femoral neck fractures. ${ }^{8,10,12}$ These fractures remain a burden in developing countries. Neglected femoral neck fracture presents with shortening, severe external rotation of the lower extremity, upward displacement of the trochanter, with or without soft tissue contracture. ${ }^{16}$ Fibular grafting has been used for neglected or non-union femoral neck fractures. ${ }^{9}$ Neglected femur fractures, other known factors such as precarious blood supply, inadequate reduction, and loss of fixation are the main reasons of non-union and avascular necrosis. ${ }^{12,17,18}$ However, there is a lack of consensus regarding treatment for neglected femoral fractures., $4,19,20$

Three of the studies mentioned used multiple cannulated screws as treatment for femoral neck fractures and most of the patients achieved bone union with minimum complications as seen in Table 2 and Table 3. Fixation with cancellous screws and fibular strut grafts for neglected femoral neck fractures is cost-effective and technically less demanding and associated with good outcomes. The femoral head is preserved and this can be converted to bipolar or total hip replacement if needed in future. ${ }^{12,21-23}$ 
Table 2. Clinical outcomes of Fibular Strut Grafts for Femoral Neck Fractures

\begin{tabular}{|c|c|c|c|c|c|c|c|c|}
\hline Author & Classification & Fractures & Intervention & $\begin{array}{c}\text { Mean } \\
\text { Delay of } \\
\text { Intervention }\end{array}$ & $\begin{array}{c}\text { Mean } \\
\text { Time of } \\
\text { Follow Up }\end{array}$ & $\begin{array}{l}\text { Clinical } \\
\text { Outcome }\end{array}$ & $\begin{array}{c}\text { Mean Time } \\
\text { of Union }\end{array}$ & Description \\
\hline $\begin{array}{l}\text { Azam } \\
\text { et al }^{8}\end{array}$ & NS & $\begin{array}{l}\text { Neglected } \\
\text { femoral } \\
\text { neck } \\
\text { fractures }\end{array}$ & $\begin{array}{l}\text { Non-vas- } \\
\text { cularized } \\
\text { fibular strut } \\
\text { graft along } \\
\text { with cancel- } \\
\text { lous screw } \\
\text { fixation }\end{array}$ & $\begin{array}{l}16.4 \text { weeks } \\
\text { (4 to } 42 \\
\text { weeks) }\end{array}$ & 4.6 years & $\begin{array}{l}\text { Anglen } \\
\text { criteria }\end{array}$ & 5.2 months & $\begin{array}{l}\text { Satisfactory bony } \\
\text { union was obtained } \\
\text { in } 25 \text { patients. Of } \\
\text { these patients, five } \\
\text { patients showed } \\
\text { excellent results; } \\
14 \text { good and six } \\
\text { had poor functional } \\
\text { result, as evaluat- } \\
\text { ed using modified } \\
\text { Anglen criteria. }\end{array}$ \\
\hline $\begin{array}{l}\text { Zahid } \\
\text { et al }{ }^{9}\end{array}$ & $\begin{array}{l}\text { Garden } \\
\text { grades III } \\
\text { and IV }\end{array}$ & $\begin{array}{l}\text { Freshly } \\
\text { displaced } \\
\text { femoral } \\
\text { neck frac- } \\
\text { tures with } \\
\text { posterior } \\
\text { commi- } \\
\text { nution } \\
\text { III: } 21 \\
\text { patients } \\
\text { IV: } 12 \\
\text { patients }\end{array}$ & $\begin{array}{l}\text { Fixation us- } \\
\text { ing } 7.0-\mathrm{mm} \\
\text { cannulated } \\
\text { cancellous } \\
\text { screws and } \\
\text { fibular } \\
\text { strut grafts }\end{array}$ & $\begin{array}{l}8.8 \text { days } \\
\text { (5 to } 21 \\
\text { days) }\end{array}$ & $\begin{array}{l}2 \text { years } \\
(1 \text { to } 4 \\
\text { years })\end{array}$ & HHS & $\begin{array}{l}4.7 \text { months } \\
\text { ( } 4.2 \text { to } 7 \\
\text { months) }\end{array}$ & $\begin{array}{l}\text { Based on HHS, out- } \\
\text { come was good to } \\
\text { excellent in } 20 \text { pa- } \\
\text { tients, fair in } 7 \text {, and } \\
\text { poor in } 6.27 \text { of the } \\
33 \text { patients achieved } \\
\text { bone union. }\end{array}$ \\
\hline $\begin{array}{l}\text { Chhetri } \\
\text { et al }{ }^{10}\end{array}$ & $\mathrm{NS}$ & $\begin{array}{l}\text { Neglected } \\
\text { femoral } \\
\text { neck } \\
\text { fractures }\end{array}$ & $\begin{array}{l}\text { Surgery } \\
\text { with fibular } \\
\text { strut graft } \\
\text { and two } \\
\text { cannulated } \\
\text { hip screws }\end{array}$ & $\begin{array}{l}4.8 \text { weeks } \\
\text { ( } 3 \text { to } 14 \\
\text { weeks) }\end{array}$ & $\begin{array}{l}39.4 \\
\text { months } \\
\text { (22 to } 80 \\
\text { months) }\end{array}$ & HHS & $\begin{array}{l}21.6 \text { weeks } \\
\text { (14 to } 48 \\
\text { weeks) }\end{array}$ & $\begin{array}{l}\text { Out of } 20 \text { fractures, } \\
17(85 \%) \text { united un- } \\
\text { eventfully, } 2(10 \%) \\
\text { had delayed union } \\
\text { and } 1(5 \%) \text { non- } \\
\text { union. The HHS was } \\
\text { excellent in } 8(40 \%) \text {, } \\
\text { good in } 4(20 \%) \text {, } \\
\text { fair in } 6(30 \%) \text { and } \\
\text { poor in } 2(10 \%) \text {. }\end{array}$ \\
\hline $\begin{array}{l}\text { Elgeidi } \\
\text { et al }{ }^{11}\end{array}$ & $\begin{array}{l}\text { Garden } \\
\text { grades III } \\
\text { and IV }\end{array}$ & $\begin{array}{l}\text { Fresh } \\
\text { femoral } \\
\text { neck frac- } \\
\text { tures with } \\
\text { posterior } \\
\text { commi- } \\
\text { nution } \\
\text { III: } 25 \\
\text { patients } \\
\text { IV: } 10 \\
\text { patients }\end{array}$ & $\begin{array}{l}\text { Closed } \\
\text { reduction, } \\
\text { internal fix- } \\
\text { ation using } \\
\text { Dynamic } \\
\text { Hip Screw } \\
\text { (DHS), and } \\
\text { fibular strut } \\
\text { grafting }\end{array}$ & 1 day & $\begin{array}{l}27.2 \\
\text { months } \\
\text { ( } 6 \text { to } 41 \\
\text { months) }\end{array}$ & HHS & $\begin{array}{l}4.8 \text { months } \\
\text { ( } 4 \text { to } 8 \\
\text { months) }\end{array}$ & $\begin{array}{l}\text { Healing of the } \\
\text { femoral neck was } \\
\text { attained in } 34 \text { cases. } \\
\text { According to the } \\
\text { HHS, outcome was } \\
\text { good to excellent in } \\
30 \text { patients, fair in } 4 \text {, } \\
\text { and poor in } 1 \text { case. }\end{array}$ \\
\hline
\end{tabular}




\begin{tabular}{|c|c|c|c|c|c|c|c|c|}
\hline $\begin{array}{l}\text { Pal et } \\
\text { al }^{12}\end{array}$ & $\begin{array}{l}\text { Garden } \\
\text { grades III } \\
\text { and IV } \\
\text { Pauwels } \\
\text { classifica- } \\
\text { tion } \\
\text { Garden } \\
\text { grades II } \\
\text { and III }\end{array}$ & $\begin{array}{l}\text { Neglected } \\
\text { femoral } \\
\text { neck } \\
\text { fractures } \\
\text { III: } 50 \\
\text { patients } \\
\text { IV: } 22 \\
\text { patients } \\
\text { Pauwels } \\
\text { I: } 10 \\
\text { patients } \\
\text { II: } 43 \\
\text { patients } \\
\text { III: } 19 \\
\text { patients }\end{array}$ & $\begin{array}{l}\text { Fixation } \\
\text { with double } \\
\text { cancellous } \\
\text { screws with } \\
\text { a single } \\
\text { fibular strut } \\
\text { graft or fix- } \\
\text { ation with } \\
\text { a single } \\
\text { cancellous } \\
\text { screw with } \\
\text { double } \\
\text { fibular strut } \\
\text { grafts }\end{array}$ & 10 weeks & 3 years & HHS & $\begin{array}{l}3 \text { to } 4 \\
\text { months: } \\
48\end{array}$ & $\begin{array}{l}\text { The HHS was } \\
\text { excellent }(90-100) \\
\text { in } 30 \text { patients, good } \\
(80-89) \text { in } 20 \text {, } \\
\text { fair }(70-79) \text { in } 15 \text {, } \\
\text { and poor }(<70) \text { in } 7 .\end{array}$ \\
\hline $\begin{array}{l}\text { Wisesa } \\
\text { et al }{ }^{13}\end{array}$ & $\begin{array}{l}\text { Garden } \\
\text { grades II } \\
\text { and III }\end{array}$ & $\begin{array}{l}\text { Fresh } \\
\text { femoral } \\
\text { neck } \\
\text { fractures } \\
\text { Garden } \\
\text { II: } 1 \\
\text { patient } \\
\text { III: } 5 \\
\text { patients }\end{array}$ & $\begin{array}{l}\text { Femoral } \\
\text { neck frac- } \\
\text { ture treated } \\
\text { with multi- } \\
\text { ple cancel- } \\
\text { lous screws } \\
\text { either with } \\
\text { or without } \\
\text { fibular graft }\end{array}$ & NS & $\begin{array}{l}24 \\
\text { months }\end{array}$ & HHS & $\begin{array}{l}16 \pm 8 \\
\text { weeks }\end{array}$ & $\begin{array}{l}\text { In all } 6 \text { patients in } \\
\text { both groups who } \\
\text { underwent surgery } \\
\text { with and without } \\
\text { fibular strut graft, } \\
\text { union was achieved } \\
\text { with excellent } \\
(100 \%) \text { HHS. }\end{array}$ \\
\hline
\end{tabular}

HHS, Harris Hip Score; NS, not specified

Table 3. Complications of Fibular Strut Grafts for Femoral Neck Fractures

\begin{tabular}{cccl}
\hline Author & Non-union & AVN & \multicolumn{1}{c}{ Other Complications } \\
\hline Azam et al $^{8}$ & 3 & 6 & $\begin{array}{l}\text { Superinfection was reported in three cases. Seven patients had minor com- } \\
\text { plains such as mild ache, ankle swelling after rigorous walking, and some } \\
\text { weakness of long toe flexors and extensors }\end{array}$ \\
\hline Zahid et al $^{9}$ & 6 & 0 & $\begin{array}{l}\text { Other complications include screw migration in the joint space (1), graft } \\
\text { migration into the joint space (3), and screw pullout (5). }\end{array}$ \\
\hline Chhetri et al $^{10}$ & 1 & 3 & $\begin{array}{l}\text { Complications were reported three weeks after intervention, including } \\
\text { shortening (5), hip screws backing out (3), head cut through by screw (1), } \\
\text { varus alignment (1), late infection (1), superficial infections (3), and donor } \\
\text { site discomfort (4). }\end{array}$ \\
\hline Elgeidi et al $^{11}$ & 1 & 0 & $\begin{array}{l}\text { Pain was the most common morbidity in patients (7), which settled down } \\
\text { in 2 months. Two patients had weakness of the extensor hallucis longus, } \\
\text { which gradually recovered over 4 months. }\end{array}$ \\
\hline Pal et al ${ }^{12}$ & 4 & 3 & $\begin{array}{l}\text { Patients who had non-union also complained persistent pain and restriction } \\
\text { of hip joint movement. }\end{array}$ \\
\hline Wisesa et al ${ }^{13}$ & 0 & 0 & $\begin{array}{l}\text { Three patients had incisional pain at the donor site and two patients had } \\
\text { initial extensor hallucis weakness which later } \\
\text { resolved in three months. }\end{array}$ \\
\hline
\end{tabular}

\section{AVN, Avascular Necrosis}

Two studies included young adults as samples and concluded that this method was beneficial for the patients. Although vascularized fibular grafts have been reported to give superior results, this method required microvascular anastomosis that most orthopedic surgeons are not commonly well versed with, which is more demanding. Thus, these studies recommended non-vascularized grafts as a dependable method for femoral neck fractures in young adults. Chhetri, et al. stated that two cancellous hip screws, one screw above and another below the graft were good enough to give good outcomes. The procedure is simple and effective with high rate of fracture union, painless, stable and mobile hip. ${ }^{8,10,24}$

Meanwhile, another half of the studies were treating fresh femoral neck fractures. ${ }^{9,11,13}$ Two of the papers specifically studied about another issue regarding femoral neck fractures which is displaced fractures, mainly posterior comminution. ${ }^{9,11}$ Posterior comminution causes instability owing to loss of the buttressing effect of the posterior cortex against external rotation. Internal fixation alone does not provide rigid fixation, owing to cavities in the posterior part of the femoral head and neck. Fractures may displace again even after fixation, and thus bone grafting 
is recommended..$^{9,25-27}$ Elgeidi, et al. reported that fixation without bone grafting resulted a non-union rate at 10 to $20 \%$ compared to only $3 \%$ in their study which utilized closed reduction with dynamic hip screw (DHS) and fibular graft. Their superior outcomes were hypothesized due to the fibular graft acting as an implant for revascularization and giving rotational stability. In addition, DHS as a screwplate system provides more stable fixation. ${ }^{11,21,28}$

However, Wisesa et al. showed relatively contradictive results. They stated that there was no added advantage of non-vascularized fibular grafting with multiple hip screw fixation in fresh femoral neck fractures in young adults over multiple hip screw fixation alone. However, they recognized that their case series had some limitations, namely small sample size and the short follow-up duration. Indeed, larger multicenter studies are required to establish a consensus on the treatment. ${ }^{13}$

Zahid, et al. even reported no avascular necrosis complications in the patients. This could be attributed to several factors. First, closed reduction by gentle manipulation avoids jeopardizing the already compromised blood supply to the femoral head. Second, fibular grafts act as biological implants for revascularization. Third, the $7.0 \mathrm{~mm}$ cannulated cancellous screws occupy less space in the femoral head. ${ }^{9}$ At last, the study recommended fibular grafting for freshly displaced femoral neck fractures with posterior comminution as an inexpensive technically less demanding procedure for retaining a stable, painless, mobile, and functional hip..$^{9,29,30}$

This systematic review has several limitations. First, all of the papers included in this review were retrospective studies, with neither clinical trials nor prospective studies. Second, we were only able to analyze the studies qualitatively, since the outcome criteria of the studies were not homogenous. Last, we also were not able to correlate the outcomes and the classification of the fractures, because the types were not described in all studies. In the future, quantitative studies using meta-analysis are needed to establish conclusions about fibular strut graft for femoral neck fractures.

\section{Conclusion}

Fibular strut graft for femoral neck fractures have shown excellent outcomes in adult patients. Fibular graft can be done with different methods, using vascularized or nonvascularized, using single or multiple cannulated cancellous screws or even dynamic hip screw. The decision on which method to use should be made by surgeons adjusting to the patients' conditions and needs. Thus, it is important to establish a consensus on surgical intervention for femoral neck fractures.

\section{Acknowledgement}

We thank Mochamadsyah Beizar Yudistira for his help during the manuscript preparation

\section{Conflict of Interest}

The author stated there is no conflict of interest

\section{References}

1. Kazley J, Bagchi K. Femoral Neck Fractures. Treasure Island (FL): StatPearls Publishing; 2020.

2. Bernstein J, Ahn J. In Brief: Fractures in Brief: Femoral Neck Fractures. Clin Orthop Relat Res. 2010 Jun;468(6):1713-5.
3. Ju DG, Rajaee SS, Mirocha J, Lin CA, Moon CN. Nationwide Analysis of Femoral Neck Fractures in Elderly Patients. J Bone Jt Surg. 2017 Nov;99(22):1932-40.

4. Jain A, Mukunth R, Srivastava A. Treatment of neglected femoral neck fracture. Indian J Orthop. 2015;49(1):17.

5. Sheehan SE, Shyu JY, Weaver MJ, Sodickson AD, Khurana B. Proximal Femoral Fractures: What the Orthopedic Surgeon Wants to Know. RadioGraphics. 2015 Sep;35(5):1563-84.

6. Slobogean GP, Sprague SA, Scott T, McKee M, Bhandari M. Management of young femoral neck fractures: Is there a consensus? Injury. 2015 Mar;46(3):435-40.

7. Liberati A, Altman DG, Tetzlaff J, Mulrow C, Gotzsche PC, Ioannidis JPA, et al. The PRISMA statement for reporting systematic reviews and metaanalyses of studies that evaluate healthcare interventions: explanation and elaboration. BMJ. 2009 Dec;339(jul21 1):b2700-b2700.

8. Azam MQ, Iraqi AA, Sherwani MKA, Sabir A, Abbas M, Asif N. Free fibular strut graft in neglected femoral neck fractures in adult. Indian $\mathrm{J}$ Orthop. 2009;43(1):62-6.

9. Zahid M, Bin Sabir A, Asif N, Julfiqar M, Khan AQ, Ahmad S, et al. Fixation using cannulated screws and fibular strut grafts for fresh femoral neck fractures with posterior comminution. J Orthop Surg (Hong Kong). 2012;20(2):191-5.

10. Chhetri RS, Khatri KP, Kharel K. Outcome of fibular strut graft and two cannulated hip screws in neglected fracture neck of femur in adults - 10 years review. J Patan Acad Heal Sci. 2019;6(1):25-30.

11. Elgeidi A, El Negery A, Abdellatif MS, El Moghazy N. Dynamic hip screw and fibular strut graft for fixation of fresh femoral neck fracture with posterior comminution. Arch Orthop Trauma Surg. 2017;137(10):13639.

12. Pal CP, Kumar B, Dinkar KS, Singh P, Kumar H, Goyal RK. Fixation with cancellous screws and fibular strut grafts for neglected femoral neck fractures. J Orthop Surg. 2014;22(2):181-5.

13. Teguh Wisesa IKI, Suryanto Dusak IW. Comparison outcome in management of femoral neck fracture using multiple cancellous screws with and without fibular graft. Int J Res Med Sci. 2020;8(9):3333.

14. Elgeidi A, El-Negery A. Fibular strut graft for nonunited femoral neck fractures in children. J Child Orthop. 2017;11(1):28-35.

15. Min B-W, Kim S-J. Avascular necrosis of the femoral head after osteosynthesis of femoral neck fracture. Orthopedics. 2011 May;34(5):349.

16. Stoica Z, Dumitrescu D, Popescu M, Gheonea I, Gabor M, Bogdan N. Imaging of avascular necrosis of femoral head: familiar methods and newer trends. Curr Heal Sci J. 2009 Jan;35(1):23-8.

17. Khani GMK, Hafeez K, Bux M, Rasheed N, Ahmed N, Anjum MP. Use of fibular bone graft and cancellous screw fixation in the management of neglected femur neck fractures in young patients. Int J Health Sci (Qassim). 11(5):7-10.

18. Nilsdotter A, Bremander A. Measures of hip function and symptoms: Harris Hip Score (HHS), Hip Disability and Osteoarthritis Outcome Score (HOOS), Oxford Hip Score (OHS), Lequesne Index of Severity for Osteoarthritis of the Hip (LISOH), and American Academy of Orthopedic Surgeons (A. Arthritis Care Res (Hoboken). 2011 Nov;63 Suppl 1:S2007.

19. Baksi DD, Pal AK, Baksi DP. Osteosynthesis of ununited femoral neck fracture by internal fixation combined with iliac crest bone chips and muscle pedicle bone grafting. Indian J Orthop. 50(4):366-73.

20. Kainth GS, Yuvarajan P, Maini L, Kumar V. Neglected femoral neck fractures in adults. J Orthop Surg (Hong Kong). 2011 Apr;19(1):13-7.

21. Jaiswal A, Pruthi KK, Goyal RK, Pathak V, Habib M, Tanwar YS, et al. Evaluation of osteosynthesis with dual fibular bone grafting for neglected femoral neck fractures. J Clin Orthop Trauma. 2013 Jun;4(2):58-69.

22. Mohapatra N, Jain G, Panigrahi T. Results of nonvascular fibula grafting with osteosynthesis in neglected fracture neck of femur. J Orthop Traumatol Rehabil. 2014;7(2):150.

23. Singh S. Long Term Results of Fresh Femoral Neck Fractures Treated by Cancellous Screw and Fibular Autograft. MOJ Orthop Rheumatol. 2014 Nov;1(3).

24. Tripathy SK, Sen RK, Goyal T. Nonvascularized fibular grafting in nonunion of femoral neck fracture: A systematic review. Indian J Orthop. 50(4):345-51.

25. Ye Y, Hao J, Mauffrey C, Hammerberg EM, Stahel PF, Hak DJ. Optimizing Stability in Femoral Neck Fracture Fixation. Hak DJ, Stahel PF, editors. Orthopedics. 2015 Oct;38(10):625-30.

26. Weinlein J, Azar F, Beaty J, Canale S. Fractures and dislocations of hip. In: Campbell's Operative Orthopaedics. 13th ed. Philadelphia: Elsevier; 2017. p. 2018-20.

27. Huang H-K, Su Y-P, Chen C-M, Chiu F-Y, Liu C-L. Displaced femoral 
neck fractures in young adults treated with closed reduction and internal fixation. Orthopedics. 2010 Dec;33(12):873.

28. Kumar S, Bharti A, Rawat A, Kumar V, Avasthi S. Comparative study of fresh femoral neck fractures managed by multiple cancellous screws with and without fibular graft in young adults. J Clin Orthop trauma. 2015 Mar;6(1):6-11.

29. Estrada LS, Volgas DA, Stannard JP, Alonso JE. Fixation failure in femoral neck fractures. Clin Orthop Relat Res. 2002 Jun;(399):110-8.

30. Mathews V, Cabanela ME. Femoral neck nonunion treatment. Clin Orthop Relat Res. 2004 Feb;(419):57-64. 